\title{
Assessment of institutional thickness in the Turkish context
}

\author{
Aksel Ersoy \\ School of Geography and Environmental Sciences, University of Birmingham, Edgbaston, Birmingham, B152TT, UK. \\ E-mail: AXE898@bham.ac.uk.Tel: 0(044) 1214143282.
}

Accepted 12 October, 2011

\begin{abstract}
The main objective of this study is to identify an indicator for the assessment of institutional thickness amongst various possible proxy measures in the Turkish context. Data for the creation of this indicator were collected at the provincial level after theorizing about studies of institutional thickness. The database includes the amount of public investment, the amount of investment incentives, the amount of municipality expenditure, the number of SMEs investment incentive certificates, the number of NGOs, the number of public buildings, the public knowledge creation variable, and the collaborative knowledge creation variable of Turkey. These variables are correlated and examined by taking their component and rotated component matrixes of them. The public knowledge creation indicator is identified as the most significant variable to describe the Turkish institutional setting. However, some commonly thought indicators remain insignificant in the analysis which raises the importance of country specific analysis.
\end{abstract}

Key words: Institutional thickness, innovation systems, Turkish regional growth.

\section{INTRODUCTION}

Institutions are the main players of the innovation systems literature and they have received a lot of attention in the field of business management, economics and economic geography (Freeman, 1987; Cooke, 1990; Lundvall, 1992; Malerba, 2002). After the emergence of the flexible-production systems, institutions have been affiliated with the concepts of 'learning regions' (Asheim, 1997; Lundvall, 1992; Maskell et al., 1998) and they have changed the direction of economic development to more 'social' and 'cultural' issues such as social consensus, institutional support for local business, innovation, skill formation and the circulation of ideas (Amin and Thrift, 1994; Asheim, 1996). Geography has a particular importance in the process of innovation and learning since these social and cultural dimensions are localized in specific places.

Considering the 'place-centredness' of these dimensions, Amin and Thrift (1994: 2) emphasize the role of certain institutions, ranging from strong local institutional presence through to the strength of shared rules and knowledge, to form the social and cultural basis of the economic success of the regions. They provide a list of the organizational components to describe the institutional thickness of a locality such as a strong institutional presence ranging from firms, training centres, government agencies, trade associations; high levels of interaction amongst the institutional network in the locality; structures of domination and patterns of coalition; and a mutual awareness of an 'industrial purpose' amongst institutions (Amin and Thrift, 1994, 1995). In the most appropriate combination of these four determinants of institutional thickness, the concept is expected to have institutional persistence; achievement of commonly held knowledge; institutional flexibility; a high innovation capacity; trust and reciprocity; and a plethora of diverse institutions to mobilise regions effectively (Henry and Pinch, 2001).

However, the concept of institutional thickness still remains as a very broad issue to conceptualize because it is essentially intangible. Some studies suggest that it is key to understanding the workings of the global economy (Amin and Thrift, 1994, 1995; Henry and Pinch, 2001; Keeble et al., 1999; Raco, 1998; Sydow and Staber, 2002), and that it enables us to understand local and 
regional capacity for collaboration and corporation in the context of globalization. However, a growing number of studies suggests that the concept does not always bring economic success and it sometimes excludes enterprises in a local economy (Eraydin, 2002; MacLeod, 1997; Raco, 1998, Taylor, 2002, 2005; Wolneberg, 2002). Therefore, the broader picture of institutional thickness, particularly its social and cultural origins and the overall changes in innovation systems, have remained elusive and less clear.

The main objective of this study is to identify an indicator for the assessment of institutional thickness amongst various possible proxy measures in the Turkish context. The identification of the concept of institutional thickness in Turkey will enhance knowledge concerning the innovation systems literature and the socio-cultural dimension of economic development in developing countries. In that sense, this study is an attempt to measure and understand the dynamics of regional innovation systems through analyzing the possible indicators developed in developed market economies. Further, the theorizing process is discussed with respect to two sets of literature that the concept of institutional thickness is built on. The methodology discusses the possible proxy measures that can represent institutional thickness in the Turkish context. Finally, those measures are correlated and an indicator for the assessment of institutional thickness is identified.

\section{THEORIZING PROCESS}

To start with, it is important to recognise that the assessment and identification of indicators are difficult, if not impossible, to measure. Data only ever portray outcomes - what has happened in the past and what is the current situation - and act only as a signpost towards what might happen in the future. It is only through theory that processes can be conjectured, making theory central to the formulation of policies to generate local economic growth. As such, regional economic policies are only as good as the theories that are used in their formulation which are relevant to the regions that are being targeted.

What is only too clear at present is that there is no shortage of theories that specify the concept of institutional thickness. What is just as unclear is which of the institutions has any empirical and practical relevance in developing the policies of national innovation systems for a country like Turkey.

At the moment, there are two sets of literature built around institutional thickness, all of which have been developed in developed country contexts, though they have been applied far more widely. These two sets of literature are built on:

1. Innovation systems (also referred to as national and regional innovation systems).

\section{Alfred Marshall's work on industrial districts.}

The literature on innovation systems explains innovation support policies as the components of systems of innovation at various spatial scales (Lundvall, 1992; Braczyk et al., 1998; Edquist, 1998). Discussions focus on institutional factors such as the structure of the research base and R\&D spending and the relationship with the trajectories of industrial innovation in key sectors. In Turkey, central government, ministries, the State Planning Institute, local authorities, local chambers and unions are the main institutions promoting local and regional economic growth. In addition to public and non-public institutions, trust, reciprocity and family circles are also very important elements (Eraydin, 1998; Saracoglu, 1993). However, even though the institutions of government and civil society appear to create institutional thickness in theory, they provide no economic resilience during a recession or over the long term (Eraydin, 2002). This can be explained via the importance of networking and access to information which remain as the central elements of the next set of literature on institutional thickness.

The literature on Alfred Marshall's work on industrial districts focuses on the agglomeration of interrelated industries in a specific region or location (Amin and Thrift, 1992; Markusen, 1996). The main reason behind this kind of agglomeration is explained through the geographical location, industrial composition, natural endowment of firms or the existence of competing industries (Maillat and Lecoq, 1992; Garnsey, 1998). It is endogenous economic growth which creates the possibility for networks and partnerships to be effective in local economies. At the heart of endogenous economic growth is 'endogenous' technological change (including 'social capital' and 'human capital') built on processes of learning-by-doing, knowledge spill-over, and Schumpeterian 'creative destruction' as entrepreneurs invest in knowledge and innovation (Martin and Sunley, 1998; Jones, 1998). Considering these two sets of literature on institutional thickness, the question is how to identify the best proxy measure that represents the concept of institutional thickness in the Turkish context. Many proxy variables have been used in studies to date (Durlauf et al., 2004). However, though those proxy variables might fit, they are, nevertheless, difficult to interpret in a meaningful way in terms of the economic reasoning. This is especially true when variable selection is driven by data availability rather than theoretical fit (Durlauf and Quah, 1999). Fortunately, although there are some challenges to finding out the best proxy measure, they are not insurmountable. Further discussion explains the selection process.

\section{METHODOLOGY}

The main objective in this stage is to identify the possible indicators 
that could represent institutional thickness in the Turkish context. This is done through identification of possible proxy measures that can represent the concept of institutional thickness. Those measures are then correlated to find out the most significant proxy measure. Principal component analysis is also undertaken to reduce the dimensionality of the dataset.

The theories of institutional thickness suggest that the concept involves a variety of different institutions including financial institutions, local chambers of commerce, training agencies, trade associations, local authorities, development agencies, Higher Education Institutions (HEls), innovation centres, clerical bodies, unions, government agencies, land and infrastructure, business service organisations, marketing boards. Within the availability of the data, various indicators are collected at the provincial level. They include the amount of public investment, the amount of investment incentives, the amount of municipality expenditure, the number of SMEs investment incentive certificates, the number of NGOs, the number of public buildings, the public knowledge creation variable, and the collaborative knowledge creation variable of Turkey. Each indicator is described further.

\section{Public investment}

Public investment in Turkey is directed by the State Planning Institute and it is aimed at meeting the expectations of public and creating a suitable physical environment where private sector can flourish. It is provided to areas where the private sector cannot succeed by itself. To have a better management process, local administrations have been empowered and they have been appointed for this role. The data are collected as per capita for each province from Turkish Statistical Institute 2004 database.

\section{Investment incentives}

Investment incentives are aimed to increase investment capacity of the State. The types of investments make this measure very important as they are subject to the production of goods and services, R\&D, environmental protection and improvement of quality and standards. Enterprises are subject to apply to the Turkish banks such as Halkbank, Turkish Development Bank, Vakifbank, Ziraat Bank and the Turkish Industrial Development Bank to get those credits. These data are created by taking the total amount of investment incentives per capita (YTL) for each province from the Turkish Statistical Institute 2003 database.

\section{Municipality expenditure}

The rapid urbanization in Turkey has increased the need for services such as transportation, health and education especially in big cities after the 1980s. In addition to the provision of physical infrastructure, various facilities have been established under Turkish municipalities such as vocational education centres. These data are collected by taking the municipality expenditures of each province per capita from the Turkish Statistical Institute 2002 database.

\section{SMEs incentive investment certificates}

After the declaration of 'the year of the SMEs' in 1996, Turkish industrial policy has been modified to subsidize the R\&D and marketing activities of the SMEs. In the $7^{\text {th }}$ Five Year Plan (1996 to 2000), a new policy towards SMEs has been adopted as the SMEs are adaptable to economic change and innovations and they have a high capacity to create employment. In that respect, investment certificates are provided to encourage and promote SMEs in Turkey. These certificates are given by the Turkish Treasury to be used for tax and VAT exemptions and free customs duties. The data are taken from the 2004 Turkish Statistical Institute database.

\section{Non governmental organisations}

Amongst the other variables, non governmental organizations (NGOs) are probably the organisations that are most commonly thought to reflect the essence of institutional thickness. The data are accessed through the website of Civil Society Development Centre ${ }^{1}$. The main concern with this database is that the total number of NGOs would be misleading in some cases. For example, each of these NGO has a different orientation, some of which would be irrelevant for the concept of institutional thickness. Although some focus on socio-cultural aspects of localities, it is difficult to comprehend to what extent others relate to the development of local economies. Therefore, this indicator should be examined very carefully.

\section{Number of public buildings}

Institutional thickness involves a variety of different institutions including firms, financial institutions, local chambers of commerce, local authorities, development agencies, government agencies, business service organisations, and the number of HEls. To make a general estimation of this indicator, the total number of the public buildings in each province can be considered to explain institutional thickness. The data are taken from the table of 'Number of Public Buildings According to Cities and Usages' of the KOSGEB (Small and Medium Enterprises Development Organisation) 2006 Regional Development Research Report which references the Turkish Statistics Institute as the main resource.

\section{Public knowledge creation}

Public knowledge creation represents a variety of institutions with the emphasis on the institutions that promote and support industries such as public and Higher Education laboratories. The public laboratories of Turkey can be directly affiliated with public institutions such as the City Control Laboratories under the Ministry of Agriculture and Rural Affairs, the Environmental Reference Laboratories under the Ministry of Environment and Forestry, or they can be indirectly affiliated with public or semi public institutions such as the Laboratories of the Turkish Standard Institutions or the Laboratories of the Scientific and Technological Research Council of Turkey. The data are taken from the table of 'Public and University Laboratories' of the KOSGEB 2006 Regional Development Research Reports which reference to the TURKLAB (The Association of Calibration and Experiment Laboratories which has been founded as an organization representing Turkey's Calibration and Experiment Laboratories on the National and International Level) 2005 study.

\section{Collaborative knowledge creation}

Collaborative knowledge creation is supported and promoted by KOSGEB to establish ORTKAs (collaborative usage studios) and ORTLABs (collaborative usage laboratories) in various cities in Turkey. KOSGEB gives support to companies and enterprises of the same interests or complementary branches of businesses to

\footnotetext{
${ }^{1}$ http://www.stgm.org.tr/eng/
} 
Table 1. Pearson correlation for the institutional thickness variable (81 observations).

\begin{tabular}{|c|c|c|c|c|c|c|c|c|}
\hline Correlation & 1 & 2 & 3 & 4 & 5 & 6 & 7 & 8 \\
\hline Public Investment (2004) & 1 & 0.059 & * & 0.024 & 0.115 & * & * & $\left.0.3511^{* *}\right)$ \\
\hline Municipality Expenditure (2002) & 0.059 & 1 & $0.637\left(^{* \star}\right)$ & $0.675\left(^{* \star}\right)$ & $0.442\left(^{* \star}\right)$ & 0.100 & $0.356\left(^{* \star}\right)$ & 0.187 \\
\hline Number of Public Buildings (2000) & * & $0.637\left({ }^{* *}\right)$ & 1 & $0.696\left(^{* \star}\right)$ & $0.359\left(^{* \star}\right)$ & 0.029 & $0.512\left(^{* \star}\right)$ & 0.080 \\
\hline Public Knowledge Creation (2005) & 0.024 & $0.675\left(^{* *}\right)$ & $0.696\left(^{* \star}\right)$ & 1 & $0.388\left(^{* *}\right)$ & * & $0.418\left(^{* *}\right)$ & 0.078 \\
\hline Amount of Investment incentive (2003) & 0.115 & $0.442\left(^{* \star}\right)$ & $\left.0.359{ }^{* \star}\right)$ & $0.388\left(^{* \star}\right)$ & 1 & 0.060 & 0.214 & * \\
\hline Collaborative Knowledge Creation (2005) & * & 0.100 & 0.029 & * & 0.060 & 1 & 0.201 & 0.100 \\
\hline SMEs Incentive Investment Certificates (2004) & * & $0.356\left(^{* *}\right)$ & $0.512\left(^{\star \star}\right)$ & $0.418\left(^{* \star}\right)$ & 0.214 & 0.201 & 1 & 0.080 \\
\hline NGO (2010) & $0.351\left({ }^{* *}\right)$ & 0.187 & 0.080 & 0.078 & * & 0.100 & 0.080 & 1 \\
\hline
\end{tabular}

${ }^{*}$ Negative values; ${ }^{* \star}$ Correlation is significant at the 0.01 level (2-tailed).

buy necessary machinery and equipment which they cannot afford to buy individually or collectively. However, the only prerequisite is that these companies and con enterprises have to come together on the basis of a joint agreement with other companies and enterprises. The number of these studios and laboratories gives us a very important indicator in terms of engagement of such institutions. The data are taken from the KOSGEB 2006 Regional Development Research Reports which reference to Turkish Statistical Institute 2004 database.

\section{FINDINGS}

The correlation of the possible indicators is required to identify which one of the indicators explains the concept of institutional thickness. The correlation matrix (Table 1) shows that some of the indicators have high significance levels. This means that these indicators are statistically explanatory. According to the correlation table, the municipality expenditures, the number of public buildings and the public knowledge creation indicators are the most encompassing indicators.

Principal component analysis is also undertaken to check whether some of the variables are correlated with one another simple because they are measuring the same construct (Table 2). The analysis is used to identify patterns in data and express the data in such a way to highlight similarities and differences. The public knowledge creation, the number of public buildings and municipality expenditures indicators are statistically significant when the component and rotated component matrixes are undertaken (Table 2). Amongst these indicators, the public knowledge creation indicator remains the most encompassing indicator. The identification of this indicator also supports the theories of institutional thickness as it supports the active local engagement of institutions, including high levels of contact, cooperation and information exchange.

In other words, the concept of institutiona thickness which suggests that a variety of different institutions including financial institutions, local chambers of commerce, training agencies, trade associations, local authorities, development agencies, Higher Education Institutions (HEIs), etc., are essential in the theories of local economic development is theoretically and statistically explained in the Turkish context.

\section{CONCLUSION AND RECOMMENDATIONS}

This paper seeks to identify, in a preliminary way, the concept of institutional thickness in the Turkish context. Possible proxy measures which can represent the concept of institutional thickness at the provincial level in Turkey are identified theoretically and correlated to find out the most significant proxy measure. They include the amount of public investment, the amount of investment incentives, the amount of municipality expenditure, the number of SMEs investment incentive certificates, the number of NGOs, the number of public buildings, public knowledge creation variable, and collaborative knowledge creation. These indicators are correlated and examined by taking the component and rotated component matrixes. The public knowledge creation indicator which supports the active local engagement of institutions, including high levels of contact, cooperation and information exchange is identified as the most significant indicator to describe the Turkish institutional settings. However, the analyses show that some indicators within the theoretical discussion such as the number of NGOs and collaborative knowledge creation do not contribute to an explanation of institutional thickness in Turkey. This proves that it is sometimes 'the processes of institutionalisation' rather than 'the presence of institutions' (Amin and 
Table 2. Component matrix and rotated component matrix of the variables.

\begin{tabular}{|c|c|c|c|}
\hline \multirow{2}{*}{ Component matrix $\left({ }^{\star}\right)$} & \multicolumn{3}{|c|}{ Component } \\
\hline & 1 & 2 & 3 \\
\hline Number of public buildings 2000 & 0.856 & -0.115 & -0.064 \\
\hline Public knowledge creation 2005 & 0.850 & -0.021 & -0.196 \\
\hline Municipality expenditures per capita per person 2002 (ytl) & 0.842 & 0.097 & -0.046 \\
\hline SMEs incentive certificates (number) 2004 & 0.639 & -0.204 & 0.343 \\
\hline Amount of investment incentives per capita 2003 (ytl) & 0.586 & 0.025 & -0.222 \\
\hline Public investment per capita per person (ytl) 2004 & 0.033 & 0.847 & -0.150 \\
\hline NGOs & 0.174 & 0.760 & 0.354 \\
\hline Collaborative Knowledge Creation 2005 & 0.132 & -0.084 & 0.872 \\
\hline \multicolumn{4}{|l|}{ Rotated component matrix $\left(^{\star}\right)$} \\
\hline Public knowledge creation 2005 & 0.872 & 0.022 & -0.024 \\
\hline Number of public buildings 2000 & 0.856 & -0.053 & 0.120 \\
\hline Municipality expenditures per capita per person 2002 (ytl) & 0.828 & 0.157 & 0.104 \\
\hline Amount of investment incentives per capita 2003 (ytl) & 0.616 & 0.043 & -0.106 \\
\hline SMEs incentive certificates (number) 2004 & 0.567 & -0.108 & 0.485 \\
\hline Public investment per capita per person (ytl) 2004 & 0.018 & 0.821 & -0.257 \\
\hline NGOs & 0.059 & 0.810 & 0.271 \\
\hline Collaborative Knowledge Creation 2005 & -0.043 & 0.037 & 0.884 \\
\hline
\end{tabular}

Extraction method: Principal component analysis; 3 components extracted.

Thrift, 1994, 1995) that generate long term benefits. This explanation is one that differs from the explanations offered by the theories of institutional thickness.

When the two other significant indicators, that is, the number of public buildings and the amount of municipality expenditure are drawn together with the public knowledge creation indicator, they suggest, tentatively, a distinctive form of innovation system across Turkey's provincial structures built on financial support by the government and driven by its public institutions. This is an interpretation that is consistent with Turkey's economic growth policies which are dominated by the central government. From the study reported here, two fundamental conclusions can be drawn. First, no current theory of institutional thickness drawn from developed country contexts provides an adequate understanding of institutional settings for a developing country context. Second, more studies from the developing countries should be undertaken to understand the broader picture of institutional thickness. It is essential to formulate policies of innovation systems that are relevant and country specific. However, government policies should first understand the impact of their institutional settings and then facilitate engagement of institutions such as high levels of contact, cooperation and information exchange.

\section{REFERENCES}

Amin A, Thrift N (1992). Neo-Marshallian nodes in global networks. Int. J. Urban Region., 16: 571-587.

Amin A, Thrift N (1994). Living in the global. In Amin A, Thrift $N$ (eds)
Globalisation, Institutions and Regional Development in Europe. Oxford: Oxford University Press.

Amin A, Thrift N (1995). Globalisation, institutional thickness and the local economy. In Healey P, Cameron S, Davoudi S, Graham S, Madinpour A (eds) Managing Cities: The New Urban Context, Chichester: Wiley

Asheim B (1996). Industrial districts as 'learning regions': a condition for prosperity. Eur. Plan. Stud., 4: 379-400.

Asheim B (1997). Learning regions in a globalised world economy: towards a new competitive advantage of industrial districts. In $M$ Taylor, S Conti (eds) Interdependent and Uneven Development: Global - Local Perspectives. Ashgate, Aldershot, Hants, pp.143-176.

Braczyk H-J, Cooke P, Heidenreich M (eds) (1998). Regional Innovation Systems. UCL Press, London and Bristol PA.

Cooke P (ed) (1990). Localities. Hutchinson, London.

Durlauf S, Johnson P, Temple J (2004). Growth econometrics. In P Aghion, S N Durlauf (eds) Handbook of Economic Growth, NorthHolland, Amsterdam.

Durlauf S, Quah D (1999). The new empirics of economic growth. In J P Taylor, M Woodford (eds) Handbook of Macroeconomics, North Holland, pp. 235-308.

Edquist C (ed) (1997). Systems of Innovation. Pinter, London.

Eraydin A (1998). From an underdeveloped region to a locality: the experience of Corum. Paper prepared for World Bank.

Eraydin A (2002). The local embeddedness of firms in Turkish Industrial Districts. In M Taylor, S Leonard (eds.) Embedded Enterprise and Social Capital: International Perspectives, Ashgate, Aldersnot, pp. 169-185.

Freeman C (1987). Technology Policy and Economic Performance: Lessons from Japan, London: Pinter

Garnsey E (1998). The genesis of the high technology milieu: a study in complexity. Int. J. Urban Reg., 22(3): 361-377.

Henry N, Pinch S (2001). Neo-Marshallian nodes, institutional thickness, and Britain's 'Motor Sport Valley': thick or thin?. Environ. Plann. A., 33: 1169-1183.

Jones C (1998). Introduction to Economic Growth. Norton, London.

Keeble D, Lawson C, Moore B, Wilkinson F (1999). Collective learning processes, networking and 'institutional thickness' in the Cambridge 
Region. Reg. Stud., 33(4): 319- 332.

Lundvall B.-A (ed.) (1992). National systems of innovation: towards a theory of innovation and interactive learning. London: Pinter.

MacLeod G (1997). Institutional thickness and industrial governance in Lowland Scotland. Area, 29: 299-311.

Maillat D, Lecoq B (1992). New technologies and transformation of regional structures in Europe: the role of the milieu. Entrepre. Regional Dev., 4: 1-20.

Malerba F. (2002). Sectoral systems of innovation and production. Res. Policy, 31: 247-264

Markusen A (1996). Sticky Places in Slippery Place: A Typology of Industrial Districts. Econ. Geogr., 72 (3): 293-313.

Martin R, Sunley P (1998). Slow convergence? The new endogenous growth theory and regional development. Econ. Geogr., 74: 201-227.

Maskell P, Eskilinen H, Hannibalsson I, Malmberg A, Vatne E (1998) Competitiveness, Localised Learning and Regional Development. Specialization and Prosperity in Small Open Economies. Routledge, London.

Raco M (1998). Assessing 'institutional thickness' in the local context: a comparison of Cardiff and Sheffield. Environ. Plann., A 30: 975-996.
Saracoglu Y (1993). Local Production Networks: An opportunity for Development. unpublished MCP Thesis, Middle East Technical University, Ankara.

Sydow J, Staber U (2002). The institutional embeddedness of project networks: the case of content production in German Television. Reg. Stud., 36(3): 215-227.

Taylor M (2002). Enterprise, embeddedness and exclusion: business and development in Fiji. TESG. 93(3): 302-315.

Taylor M (2005). Embedded local growth: a theory taken too far? In R Boschma, R Kloosterman (eds.) Learning from Clusters: A Critical Assessment from an Economic-Geographical Perspective.

Wolneberg K (2002). Supply, chains, embeddedness and the restructuring of Argentina's tanning industry. In M Taylor, S Leonard (eds.) Embedded Enterprise and Social Capital: International Perspectives, Ashgate, Aldersnot, pp. 57-76. 